\title{
TELAAH ASPEK BUDAYA DALAM ARSITEKTUR PENDOPO MANGGALA PRAJA NUGRAHA DI KABUPATEN TRENGGALEK
}

\author{
Subyantoro Retno Pamuji ${ }^{*}$, Junianto Hadi Wiryono ${ }^{2}$ \\ Mahasiswa Program Magister Arsitektur Universitas Merdeka Malang ${ }^{1}$, \\ Dosen Program Studi Magister Arsitektur ${ }^{2}$ \\ *subyantoro77@gmail.com
}

\begin{abstract}
ABSTRAK
Rumah tradisional Jawa merupakan salah satu kebudayaan peninggalan nenek moyang suatu masyarakat dari masa lalu, dikenal dengan nama Rumah Joglo. Namun pada perkembangannya saat ini, rumah tinggal masyarakat tradisional Jawa telah mengalami banyak perubahan, baik dalam bentuk, ruang maupun penggunaan ornamen dan bahan bangunan. Maka dari itu mendalami sejauh mana rumah adat Jawa ini Pendopo Manggala Praja Nugraha di Kabupaten Trenggalek diadopsi dari sisi budaya menjadi sangat penting untuk diketahui. Tujuan dari penulisan artikel ini adalah untuk mengetahui bentuk, ornamen, interior dan tata ruang pendopo Manggala Praja Nugraha ditinjau dari aspek budaya Jawa. Metode yang dipakai dalam penulisan artikel ini adalah studi literatur dari berbagai jurnal dan artikel ilmiah. Dari tujuan diatas maka rumusan masalah adalah bagaimana bentuk, ornamen, interior dan tata ruang pendopo Manggala Praja Nugraha ditinjau dari aspek budaya Jawa . Hasil yang didapatkan bahwa dari aspek bentuk pendopo tersebut masih kental mengadopsi budaya jawa namun dari sisi ornamen dan interior sedikit sekali mengadopsi unsur budaya jawa.
\end{abstract}

Kata kunci: Joglo, Ornamen, Pendopo.

\section{ABSTRACT}

The traditional Javanese house is one of the cultural heritage of a society's ancestors from the past, known as the Joglo House. However, in its current development, traditional Javanese houses have undergone many changes, both in form, space and use of ornaments and building materials. Therefore, exploring the extent to which this Javanese traditional house, the Manggala Praja Nugraha Hall in Trenggalek Regency, was adopted from a cultural perspective, is very important to know. The purpose of writing this article is to determine the shape, ornament, interior and layout of the Manggala Praja Nugraha pavilion in terms of Javanese cultural aspects. The method used in writing this article is literature study from various journals and scientific articles. From the above objectives, the formulation of the problem is How the shape, ornament, interior and layout of the Manggala Praja Nugraha pavilion in terms of Javanese cultural aspects. The results show that the shape of the pavilion still adopts Javanese culture, but in terms of ornamentation and interior, it has very little adoption of Javanese cultural elements.

Keywords: Joglo, Ornamen, Pendopo. 


\section{PENDAHULUAN}

\section{Latar Belakang}

Ditemukannya benda-benda yang merupakan hasil zaman Nirloka membuktikan bahwa Trenggalek telah dihuni oleh manusia sejak zaman prasejarah. Menurut Hermansyah (1979) dalam Purwadi (2011) penemuan sejumlah benda-benda purbakala menandai masa prasejarah budaya Jawa. Zaman sejarah di tanah Jawa ditandai dengan adanya prasasti yang pertama kali muncul berbentuk Prasasti Kampak atau dikenal dengan namanya Perdikan Kampak di Kabupaten Trenggalek (Purwadi, 2011). Prasasti Kampak atau Prasasti Kamsyaka yang dikeluarkan Raja Sindok pada 929 menetapkan daerah Kampak sebagai daerah sima swatantra atau daerah otonom (Budiharso, 2015).

Kabupaten Trenggalek sendiri adalah salah satu kabupaten yang terletak di pesisir pantai selatan pulau jawa berbatasan langsung dengan Kabupaten Tulungagung, Kabupaten Pacitan dan Kabupaten Ponorogo. Secara administrasi berada di bawah wilayah pemerintahan Propinsi Jawa Timur. Kabupaten Trenggalek merupakan daerah otonom yang berbentuk kabupaten yang sampai dengan saat ini dipimpin oleh seorang bupati. Dari masa kemasa bupati ini bertempat tinggal di sebuah bangunan yang lebih dikenal dengan pendopo. Sejak tanggal 2 April 2013 Kabupaten Trenggalek telah meresmikan nama baru pendoponya yaitu "MANGGALA PRAJA NUGRAHA" yang artinya anugerah atau berkah berupa kebahagiaan dan keberuntungan bagi Pemimpin dan Rakyat. Menurut manuskrip Kraton Kasunanan Surakarta, kata Trenggalek secara sederhana ialah kota gaplek atau daerah penghasil gaplek yang muncul pada zaman Raja Mataram sebelum Mpu Sindok, yaitu Rakai Dyah Wawa (924-928) (Budiharso, 2015). Sri Susuhunan Pakubuwana II, raja terakhir Kasunanan Kartasura (1726-1742) dan raja pertama Kasunanan Surakarta (1745-1749), ialah raja yang berjasa menggunakan nama Trenggalek secara resmi dalam administrasi pemerintahan (Budiharso, 2015).

Menurut Withkamp dalam Handinoto, tipologi Ibukota kabupaten di Jawa memiliki tata kota yang didominasi oleh alun-alun yang terletak di pusat kota (Handinoto dan Paulus $\mathrm{H}$. Soehargo, 1996). Pada sumbu utara - selatan di kedua ujung alun-alun terletak kediaman Asisten Residen dan Bupati yang saling berhadapan, namun pendopo Manggala Praja Nugraha Sendiri terletak di sebelah Timur Alon-Alon Kabupaten yang secara konsep tata kota tradisional Jawa tidak menganut Catur Tunggal (Ramdlani, 2012). Akan tetapi disini penulis tidak akan mengulas hal itu, disini penulis akan mengulas tentang bangunan pendopo itu sendiri dengan tujuan untuk mengetahui sejauh mana pengaruh budaya jawa masih melekat pada bangunan pendopo Manggala Praja Nugraha. Pendopo merupakan bagian dari sebuah rumah tradisional Jawa, selain karena letaknya yang terdapat pada bagian paling 
depan, fungsi pendopo adalah tempat untuk bersosialisasi dengan keluarga, kerabat maupun tetangga, sehingga menjadi sangat penting keberadaannya (Maria I Hidayatun, 1999).

\section{Landasan Teori}

Bentuk menurut D.K.Ching, 1996 dalam Hermawan \& Prihatmaji, (2019) adalah merupakan perwujudan fisik penampilan luar yang dapat dilihat serta dikenali dengan mudah. Bentuk sendiri terdiri atas unsur bantuk dasar, ukuran, tekstur dan warna. Pada prinsipnya rumah Jawa tersusun sesuai bagian anatomi tubuh manusia yang terdiri dari pondasi atau batur (kaki), tiang atau saka (badan), empyak atau atap (Kepala), ini adalah merupakan dasar atau basis dari keseluruhan bangunan dan merupakan bagian yang sangat menentukan $(\mathrm{N}$. Widayati, 1999). Perspektif vertikal membagi rumah Joglo menjadi tiga kelompok yang terdiri dari lantai dasar atau kaki yang disebut umpak atau bebatur, tubuh yang terdiri dari tiang dan dinding, dan bagian atas terdiri dari kepala atau atap (Djono, T. P. Utomo, 2012).

Menurut N. Widayati, 1999 Bangunan rumah tradisional jawa pada mulanya terdiri dari satu ruang yang kemudian berkembang baik dari segi ruang maupun segi bentuk yang disebabkan adanya perkembangan sistem kehidupan maupun faktor kebutuhan akan ruang. Salah satu bentuk yang berkembang adalah bentuk atap panggang pe ke bentuk kampung kemudian ke bentuk limasan dan akhirnya ke bentuk joglo. Tata Letak Rumah Joglo khususnya penempatan area servis pada bangunan terpisah dari rumah induk (E. Widayati et al., 2019). Menurut Frick, (1997:33) perwujudan atap bangunan tradisional jawa dapat dikelompokkan menjadi tiga. Pertama, atap yang biasa digunakan oleh rakyat biasa seperti atap kampung dan limasan. Kedua, atap yang biasa digunakan oleh kaum bangsawan yaitu joglo . Ketiga atap tajuk yang digunakan untuk bangunan-bangunan sakral seperti masjid atau kuil (Pitana, 2007).

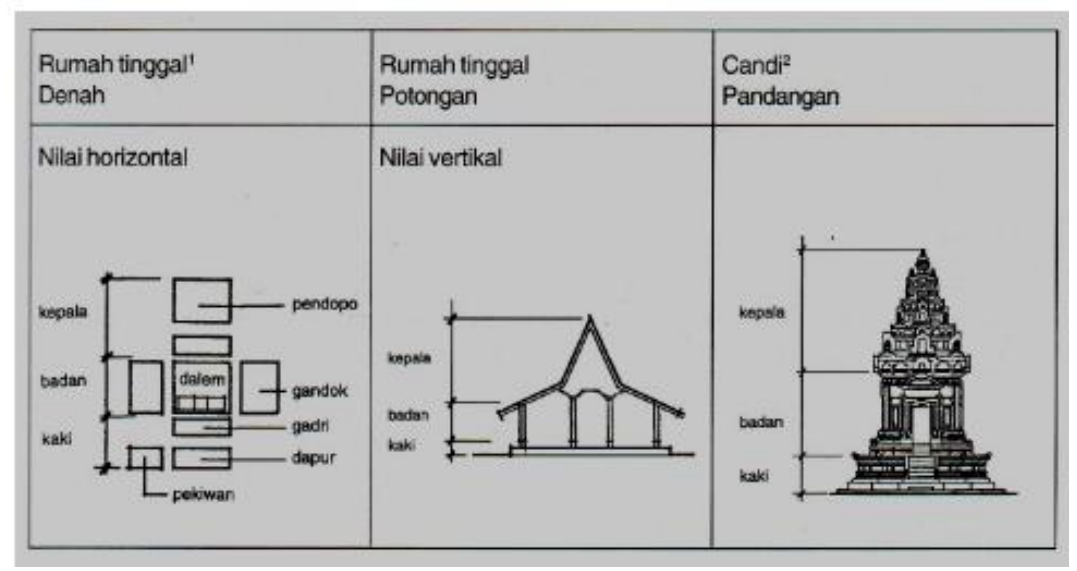

Gambar 1. Konsep pembagian bangunan Jawa (sumber:Frick, 1997)

Dari sisi denah biasanya merupakan bentuk persegi dapat berbentuk bujur sangkar atau segi empat tergantung pada atapnya yang secara konseptual mempunyai arti filosopis yang 
menggambarkan bentuk geometri dari makro kosmos (Maria I Hidayatun, 1999). Sedangkan makna fungsional bentuk persegi yang dilengkapi dengan empat sisi yang terbuka melambangkan keterbukaan dari sang pemilik yang siap menerima siapa saja secara terbuka (Maria I Hidayatun, 1999). Hal ini juga di sampaikan oleh Widayatsari, S., (2002), dimana pendopo diklasifikasikan dalam area semi publik dari segi pengguna dan aktivitas setelah mendapatkan pengaruh Eropa berupa kuncung. Kuncung ini menjadi suatu bentuk baru pada rumah Jawa setelah masuknya Eropa ke tanah Jawa. (Widiyatsari, 2002).

Ornamen atau dalam kamus besar bahasa indonesia memiliki makna hiasan dalam arsitektur. Dalam bangunan tradisional jawa hiasan arsitektur ini meliputi flora, fauna, alam dan religi (Gerarda Orbita Ida Cahyandari, 2012).

Tabel 1. Ragam Hias Faua : Arti dan Penempatan

\begin{tabular}{|c|c|c|c|}
\hline Nama & Wujud & Letak & Arti \\
\hline Kemamang & $\begin{array}{l}\text { Kala (raksasa, hantu). } \\
\text { Selalu diberi warna }\end{array}$ & $\begin{array}{l}\text { Di bagian depan pintu } \\
\text { gerbang, benteng atau } \\
\text { pintu lingkungan Kraton }\end{array}$ & $\begin{array}{l}\text { Menelan segala sesuatu } \\
\text { yang jahat yang } \\
\text { berkehendak masuk. }\end{array}$ \\
\hline $\begin{array}{l}\text { Peksi Garuda } \\
\text { foge }\end{array}$ & $\begin{array}{l}\text { Burung Garuda. Dengan } \\
\text { warna emas. }\end{array}$ & $\begin{array}{l}\text { Bubungan, tebeng } \\
\text { (papan datar di atas } \\
\text { pintu, jrndela) senthong } \\
\text { tengah dan patang aring, } \\
\text { dan gerbang. }\end{array}$ & Pemberantas kejahatan \\
\hline 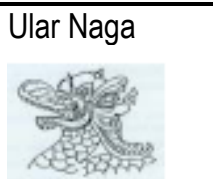 & $\begin{array}{l}\text { Warna emas, putih, atau } \\
\text { tembaga.Berhadapan, } \\
\text { tolak belakang, berjajar, } \\
\text { atau berbelitan }\end{array}$ & $\begin{array}{l}\text { Di pintu gerbang dan } \\
\text { Bubungan Rumah }\end{array}$ & $\begin{array}{l}\text { Menghilangkan } \\
\text { penyebab bencana }\end{array}$ \\
\hline 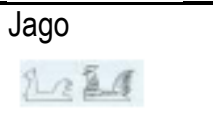 & Ayam Jantan & $\begin{array}{l}\text { Di atas bangunan di } \\
\text { ujung bubungan }\end{array}$ & $\begin{array}{l}\text { Kejantanan, keberanian, } \\
\text { kekuatan batin dan fisik }\end{array}$ \\
\hline $\begin{array}{l}\text { Mirong } \\
|y| y \mid \\
5 \mid\end{array}$ & $\begin{array}{l}\text { Sikap malu atau susah } \\
\text { sekali, kemudian } \\
\text { meninggalkan tempat itu. } \\
\text { Putri mungkur (dari } \\
\text { belakang), putir mirong. }\end{array}$ & $\begin{array}{l}\text { Di tiang-tiang bangunan } \\
\text { saka guru, saka } \\
\text { penanggap, penitih }\end{array}$ & $\begin{array}{l}\text { Kepercayaan perwujudan } \\
\text { Kanjeng Ratu Kidul }\end{array}$ \\
\hline
\end{tabular}

Sumber : Dakung, 1981/1982:139-193 dalam Gerarda Orbita Ida Cahyandari, (2012) 
Tabel 2. Ragam Hias Flora : Arti dan Penempatan

\begin{tabular}{|c|c|c|c|}
\hline Nama & Wujud & Letak & Arti \\
\hline 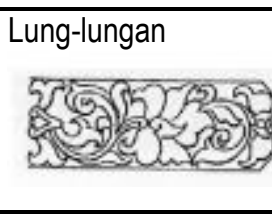 & $\begin{array}{l}\text { Tumbuhan menjalar } \\
\text { dengan daun, bunga dan } \\
\text { buah dengan warna } \\
\text { merah, hijau, kuning, } \\
\text { biru, ungu }\end{array}$ & $\begin{array}{l}\text { Umumnya terdapat di } \\
\text { bagian balok rangka } \\
\text { atap, pamidangan, } \\
\text { tebeng pintu, jendela, } \\
\text { dan patang aring. }\end{array}$ & Estetika dan wingit \\
\hline 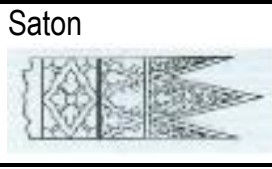 & $\begin{array}{l}\text { Bentuk persegi dengan } \\
\text { hiasan daun dan bunga. } \\
\text { Warna hijau, merah } \\
\text { saton emas. }\end{array}$ & $\begin{array}{l}\text { Ragam hias terletak di } \\
\text { balok rangka atap, tiang } \\
\text { bangunan atas bawah, } \\
\text { tebeng pintu }\end{array}$ & Keindahan \\
\hline Wajikan & $\begin{array}{l}\text { Berbentuk belah ketupat. } \\
\text { Berisi daun atau bunga. } \\
\text { Warna yang kontras }\end{array}$ & $\begin{array}{l}\text { Ragam hias terletak di } \\
\text { tengah tiang atau pada } \\
\text { persilangan balok pagar } \\
\text { bangunan }\end{array}$ & Estetika dan wingit \\
\hline 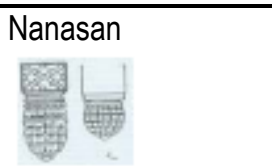 & $\begin{array}{l}\text { Mirip nanas, omah } \\
\text { tawon, atau prit gantil. } \\
\text { Warna sesuai dengan } \\
\text { bangunan }\end{array}$ & & $\begin{array}{l}\text { Keindahan dan usaha } \\
\text { keras untuk } \\
\text { mendapatkan } \\
\text { kebahagiaan }\end{array}$ \\
\hline
\end{tabular}

\begin{tabular}{|c|c|c|c|}
\hline $\begin{array}{l}\text { Tlacapan } \\
\text { A } A \Delta A \Delta A A\end{array}$ & $\begin{array}{l}\text { Deretan segitiga sama } \\
\text { tinggi. Polos atau berisi } \\
\text { lung-lungan. Warna } \\
\text { emas dengan dasar hijau } \\
\text { atau merah tua. }\end{array}$ & $\begin{array}{l}\text { Pangkal dan ujung balok } \\
\text { kerangka bangunan }\end{array}$ & $\begin{array}{l}\text { Sinar matahari atau } \\
\text { sorotan berarti kecerahan } \\
\text { dan keagungan }\end{array}$ \\
\hline & $\begin{array}{l}\text { Mirip buah keben, } \\
\text { persegi meruncing } \\
\text { seperti mahkota }\end{array}$ & $\begin{array}{l}\text { Blandar tumpang ujung } \\
\text { bawah joglo dan ujung } \\
\text { bawah saka benthung } \\
\text { lambang gantung }\end{array}$ & $\begin{array}{l}\text { Keindahan dan proses } \\
\text { dari yang tidak sempurna } \\
\text { menuju sempurna }\end{array}$ \\
\hline 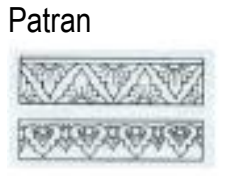 & $\begin{array}{l}\text { Dari kata patra berarti } \\
\text { daun, Berbentuk daun } \\
\text { berderet }\end{array}$ & $\begin{array}{l}\text { Tepian atau hiasan pada } \\
\text { bidang datar kecil dan } \\
\text { memanjang di bagian } \\
\text { balok rangka bangunan }\end{array}$ & $\begin{array}{l}\text { Keindahan dan } \\
\text { kesempurnaan }\end{array}$ \\
\hline $\begin{array}{l}\text { Padma } \\
+\infty\end{array}$ & $\begin{array}{l}\text { Bunga teratai berwarna } \\
\text { merah }\end{array}$ & $\begin{array}{l}\text { Terletak diatas tiang } \\
\text { (umpak) }\end{array}$ & $\begin{array}{l}\text { Estetika dan kesucian } \\
\text { (padma), kokoh, kuat }\end{array}$ \\
\hline
\end{tabular}

Sumber : Dakung, 1981/1982:139-193 dalam Gerarda Orbita Ida Cahyandari, (2012) 
Tabel 3. Ragam Hias Alam : Arti dan Penempatan

\begin{tabular}{|c|c|c|c|}
\hline Nama & Wujud & Letak & Arti \\
\hline 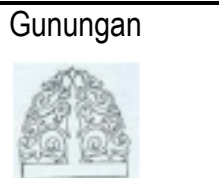 & $\begin{array}{l}\text { Bentuk gunung secara } \\
\text { sederhana atau bentuk } \\
\text { pohon }\end{array}$ & $\begin{array}{l}\text { Bubungan rumah di } \\
\text { tengah }\end{array}$ & $\begin{array}{l}\text { Lambang alam semesta } \\
\text { dengan puncak } \\
\text { keagungan. Kayon atau } \\
\text { pohon untuk berlindung. }\end{array}$ \\
\hline Makutha & Mahkota & $\begin{array}{l}\text { Bubungan atap di tengah } \\
\text { atau bagian tepi kanan } \\
\text { kiri }\end{array}$ & $\begin{array}{l}\text { Raja wakil dari Tuhan } \\
\text { memberkahi seisi rumah } \\
\text { agar selamat }\end{array}$ \\
\hline 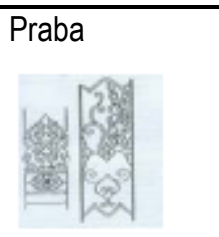 & $\begin{array}{l}\text { Ukiran berbentuk } \\
\text { melengkung meninggi } \\
\text { dengan berujung di } \\
\text { tengah. Mirip daun- } \\
\text { daunan atau ekor merak }\end{array}$ & $\begin{array}{l}\text { Di tiang-tiang (saka) } \\
\text { sebelah atas dan bawah } \\
\text { pada keempat sisi tiang. }\end{array}$ & $\begin{array}{l}\text { Sinar atau memberikan } \\
\text { cahaya pada tiang-tiang, } \\
\text { sehingga menambah } \\
\text { keindahan. }\end{array}$ \\
\hline 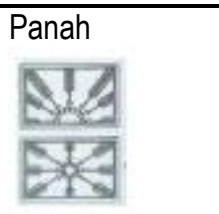 & $\begin{array}{l}\text { Anak panah yang menuju } \\
\text { ke satu titik dalam bidang } \\
\text { segiempat }\end{array}$ & $\begin{array}{l}\text { Tebeng pintu (sebelah } \\
\text { atas pintu), sembarang } \\
\text { pintu }\end{array}$ & $\begin{array}{l}\text { Sebagai ventilasi, } \\
\text { delapan senjata dari } 8 \\
\text { arah mata angin dapat } \\
\text { sebagai penolak bala. }\end{array}$ \\
\hline $\begin{array}{l}\text { Kepetan } \\
\\
\end{array}$ & $\begin{array}{l}\text { Bentuk } 1 / 4 \text { lingkaran, sisi } \\
\text { lengkung berombak }\end{array}$ & $\begin{array}{l}\text { Di patang aring } \\
\text { senthong, daun pintu, } \\
\text { dinding gebyok. }\end{array}$ & $\begin{array}{l}\text { Sumber penerangan bagi } \\
\text { seisi rumah (lambang } \\
\text { matahari jaman Hindhu) }\end{array}$ \\
\hline Mega mendung & $\begin{array}{l}\text { Awan putih dan awan } \\
\text { hitam }\end{array}$ & $\begin{array}{l}\text { Tepi blandar, pintu, } \\
\text { tebeng jendela, tebeng } \\
\text { sekat. }\end{array}$ & $\begin{array}{l}\text { Sifat mendua : laki-laki } \\
\text { perempuan, hitam putih, } \\
\text { siang malam, baik buruk. }\end{array}$ \\
\hline $\begin{array}{l}\text { Banyu tetes } \\
\text { (4) }\end{array}$ & $\begin{array}{l}\text { Tetesan air yang terkena } \\
\text { sinar matahari }\end{array}$ & $\begin{array}{l}\text { Bersamaan dengan } \\
\text { patran, pada rangka }\end{array}$ & $\begin{array}{l}\text { Tiada kehidupan tanpa } \\
\text { air, keindahan }\end{array}$ \\
\hline
\end{tabular}

Sumber : Dakung, 1981/1982:139-193 dalam Gerarda Orbita Ida Cahyandari, (2012)

Bangunan adat Jawa memiliki ornamen-ornamen yang dijadikan sebagai ciri khas bangunan adat tradisional Jawa. Keraton merupakan pusat kebudayaan masyarakat Jawa dan dapat dipastikan merupakan transformasi dari konsep filosofi Jawa (Rachman \& Semarang, 2012). Untuk ornamentatif dekoratif, bangunan di pusat kebudayaan Jawa yaitu di keraton mempunyai banyak ragam hias flora yang diwarnai merah, hitam, hijau, putih dan kuning keemasan (Lukito Kartono, 2005). 
Berbeda dengan tata ruang modern di mana area layanan terintegrasi ke dalam rumah utama, namun konsep tata letak Rumah Joglo, terutama penempatan area layanan di gedung terpisah dari rumah utama (E. Widayati et al., 2019).

1

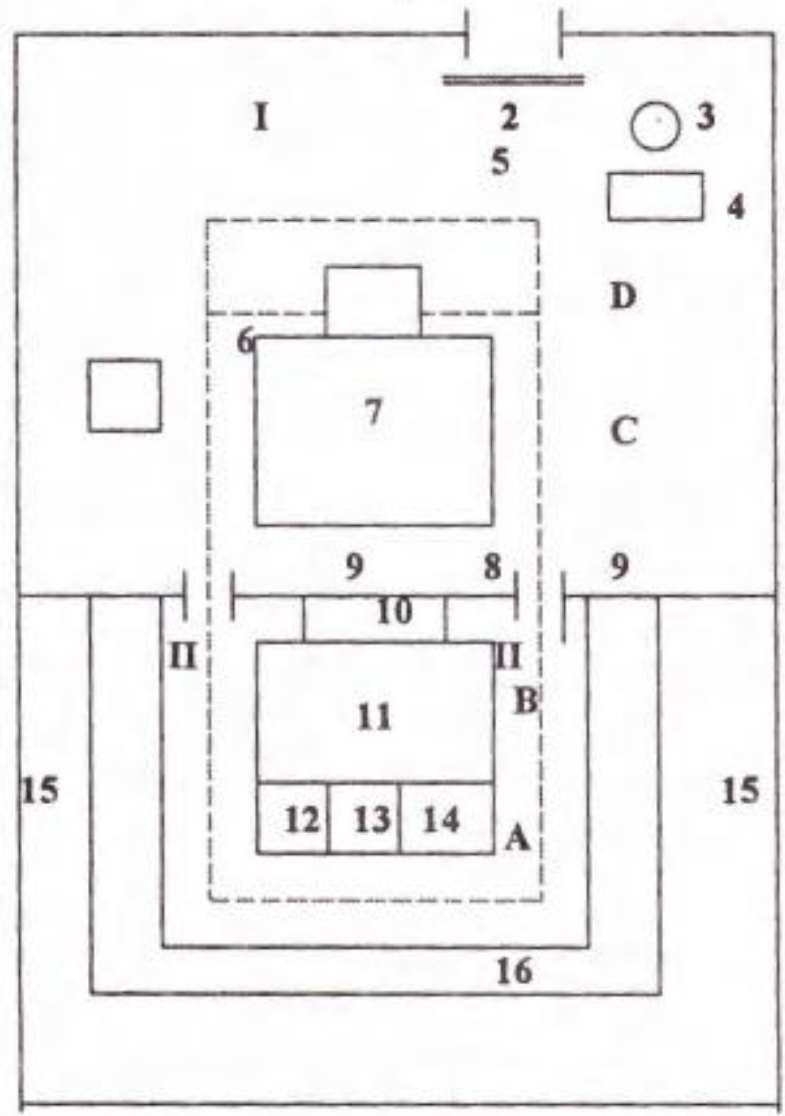

Keterangan :

1. Regol

2. Rana

3. Sumur

4. Langgar

5. Kuncung

6. Kandang kuda

7. Pendapa

8. Longkangan

9. Seketheng

10. Pringitan

11. Dalem

12. Senthong kiri

13. Senthong tengah

14. Senthong kanan

15. Gandok

16. Dapur, dan lain-lain

I. Halaman luar

II. Halaman dalam

$A$ dan $B=$ privat

C = semi privat

D $=$ umum

Gambar 2. Skema kompleks bentuk rumah Joglo dan pembagian ruangnya (sumber:Dakung dalam Widayati, 1999)

Dalam sistem struktur bangunan tradisional Jawa, struktur atap ditopang dan diikat oleh saka (kolom atau tiang), yang kemudian diteruskan ke pondasi bangunan yang berbentuk umpak (pondasi setempat yang terbuat dari batu berbentuk trapesium). Kolom utama penyangga atap bangunan adalah saka guru, yang berjumlah 4 buah. Jumlah saka guru ini merupakan simbol adanya pengaruh kekuatan empat penjuru mata angin yang biasa disebut konsep Pajupat. Dalam konsep ini manusia dianggap berada di tengah perpotongan arah mata angin, tempat yang dianggap mengandung getaran magis yang amat kuat selanjutnya disebut sebagai pancer atau manunggaling keblat papat (Pitana, 2007).

Konsep warna Jawa berbeda dengan warna barat modern. Contoh konsep warna Jawa seperti gula-klapa (merah-putih) warna Kraton Surakarta, kemudian pare-anom (kuning-hijau) warna Mangkunegaran (Sumardjo, 2013). Tulisan ini dimaksudkan untuk menjelaskan bagaimana bentuk bangunan pendopo Manggala Praja Nugraha di tinjau dari aspek budaya, bagaimana 
ornamen bangunan pendopo Manggala Praja Nugraha di tinjau dari aspek budaya Jawa, dan bagaimana tata ruang dan interior bangunan pendopo Manggala Praja Nugraha di tinjau dari aspek budaya Jawa.

\section{METODE PENELITIAN}

Penelitian ini termasuk dalam penelitian deskriptif, Metode yang digunakan adalah studi literatur, wawancara dan melakukan pengamatan langsung kepada obyek penelitian yakni Pendopo Manggala Praja Nugraha Kabupaten Trenggalek. Penelitian pertama adalah mengamati bentuk Pendopo yang kemudian di analisis dengan landasan teori yang telah di tulis di atas. Kemudian Tahap kedua melakukan pengamatan terhadap ornamen-ornamen yang ada pada bangunan pendopo yang kemudian di analisis dengan landasan teori yang ada. Tahap Terakhir mengamati tata ruang pendopo yang dianalisis menggunakan landasan teori yang telah ada.

\section{HASIL DAN PEMBAHASAN}

Berdasarkan hasil pengamatan yang dilakukan dan dikaji berdasarkan landasan teori yang ada, dalam pembahasan ini untuk mengetahui aspek budaya dalam arsitektur Pendopo Manggala Praja Nugraha di Kabupaten Trenggalek di bagi menjadi 3 obyek yang diteliti. Adapun obyek pertama adalah bentuk pendopo itu sendiri, kemudian obyek kedua adalah ornamenornamen yang ada dan yang ketiga adalah obyek tata ruang dan interior. Untuk pembahasan lebih lengkap dapat dilihat pada narasi di bawah ini:

\section{Bentuk Pendopo Manggala Praja Nugraha}

Bagian pendopo yang paling mudah dikenali adalah bentuk fisiknya yakni atap dari bangunan tradisional Jawa. Bentuk Joglo mempunyai dominasi yang kuat dari bangunan pendopo tersebut. Pendopo Manggala Praja Nugraha dilihat dari bentuk atap masih menunjukkan adanya keterkaitan dengan budaya Jawa. Karena unsur kepala, badan dan kaki masih tampak jelas dalam wujud bangunannya. Sedangkan dari sisi denah merupakan bentuk persegi yang dilengkapi dengan empat sisi. Pada saat ini denah Pendopo Manggala Praja Nugraha sudah ada bangunan tambahan yaitu kuncung dibagian depan dan dinding di bagian belakang sehingga dapat dikatakan sudah bergeser dari makna sebelumnya (bangunan semi publik). Hal ini telah disampaikan oleh Widayatsari, S., (2002), dimana pendopo diklasifikasikan dalam area semi publik dari segi pengguna dan aktivitas setelah mendapatkan pengaruh Eropa berupa kuncung. Kuncung ini menjadi suatu bentuk baru pada rumah Jawa setelah masuknya Eropa ke tanah Jawa, dan hal ini telah diadopsi oleh bentuk bangunan Pendopo Manggala Praja Nugraha. 
Dari segi ukuran pendopo Manggala Praja Nugraha memiliki ukuran yang luas sehingga secara konsep masih sesuai dengan makna ruang pendopo itu sendiri sebagai tempat berkumpul atau bersosialisasi dengan masyarakat. Sampai dengan saat inipun masih difungsikan sebagai tempat mengumpulkan masyarakat maupun abdi negara di lingkungan Pemerintah Kabupaten Trenggalek.

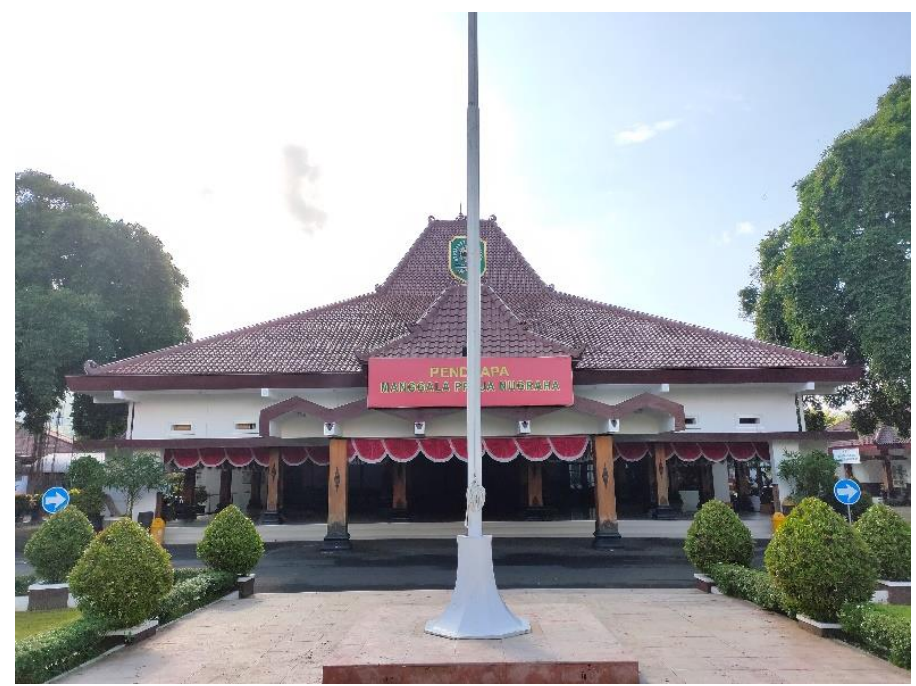

Gambar 3. Pendopo Manggala Praja Nugraha Trenggalek (sumber:Kominfo Trenggalek, 2020)

\section{Ornamen pada Pendopo Manggala Praja Nugraha}

Berdasarkan pada landasan-landasan teori diatas, saat ini Pendopo Manggala Praja Nugraha masih terlihat menerapkan beberapa ornamen daam bangunannya, hal ini terlihat adanya unsur-unsur ukiran yang melekat pada tiang/saka pendopo, pada backdrop maupun pada balok-balok pengikat antar tiang. Ukiran pada tiang pendopo bawah maupun atas berjenis "praba" dengan ciri ukiran berbentuk melengkung meninggi dengan berujung di tengah. Kemudian ornmen pada lantainya yang menunjukkan adanya lukisan batik yang juga memberikan gambaran merupakan warisan budaya Jawa. Kemudian ornamen yang ada pada lantai menunjukkan adanya lukisan batik yang berkonsep Flora atau tanaman. Ornamen lain yang ada pada atap adalah makutha atau mahkota yang terletak pada bubungan atap bagian tepi kanan dan kiri. 


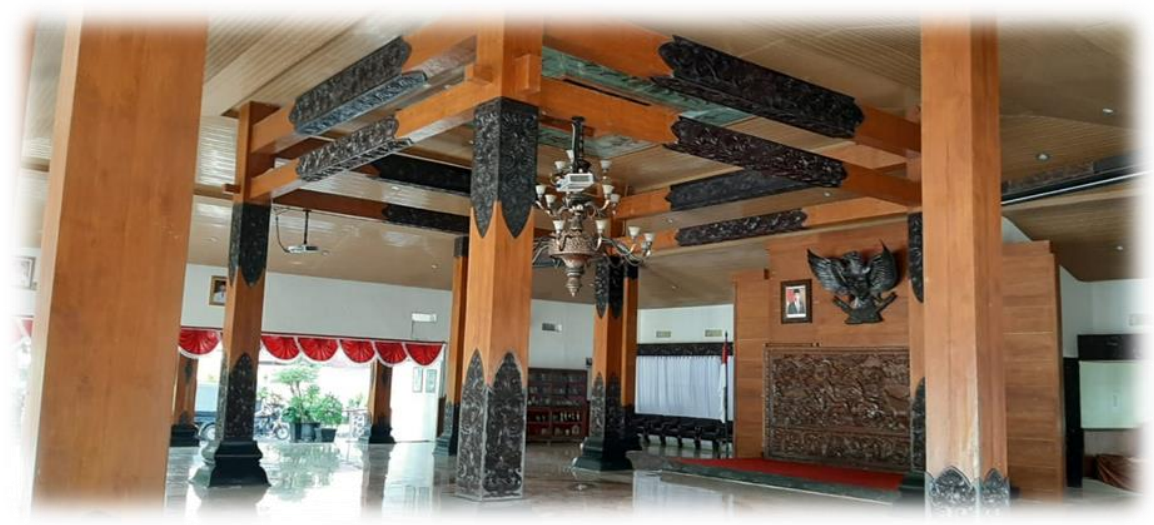

Gambar 4. Ruang Dalam Pendopo (sumber:Survey, 2020)

\section{Interior dan Tata Ruang}

Berbeda dengan tata ruang rumah modern di mana area layanan terintegrasi ke dalam rumah utama, namun konsep tata letak rumah Joglo, terutama penempatan area layanan di gedung terpisah dari rumah utama (E. Widayati et al., 2019). Pendopo menurut E. Widayati et al.,(2019) berfungsi sebagai ruang tamu atau ruang pertemuan yang juga mencerminkan kearifan dan kekuatan persatuan, mengusung filosofi guyub yang memiliki makna pusat kerukunan dan tempat berkumpul bagi penduduk dari masyarakat sekitar. Pendopo merupakan bangunan profone yang berada di bagian depan serta berfungsi sebagai penerima (Pitana, 2007). Menurut Priyotomo (1984) dalam Lukito Kartono, (2005) pendopo merupakan sarana untuk berkomunikasi dengan sesama manusianya.

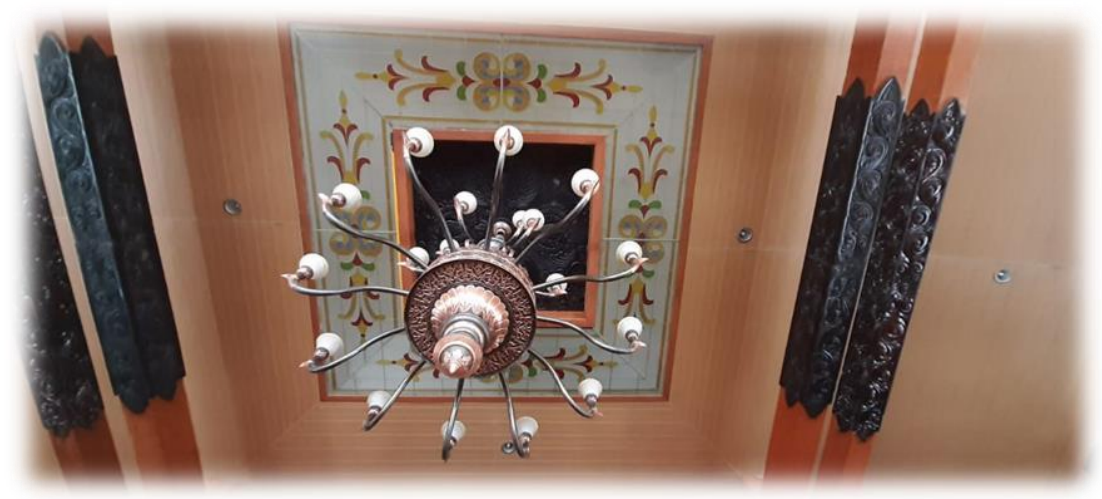

Gambar 5. Langit-langit Manggala Praja Nugraha Trenggalek (sumber:Survey, 2020) 


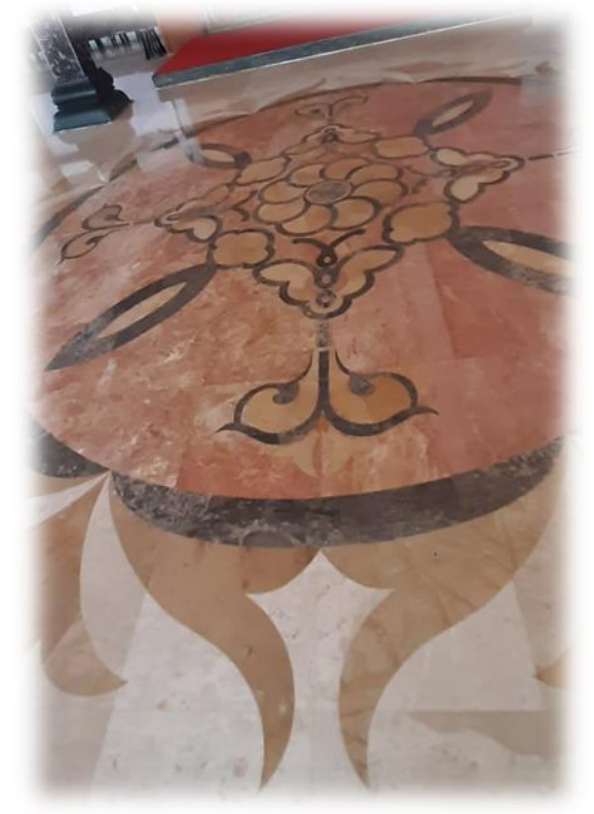

Gambar 6, Lantai Manggala Praja Nugraha Trenggalek (sumber:Survey, 2020)

Dalam hal ini Pendopo Mangagal Praja Nugraha masih relevan dengan konsep budaya Jawa. Jika ditinjau dari letak dalam komplek Rumah Joglo maka pendopo berada di paling depan. Bangunan ini merupakan bangunan terpisah dari komplek perumahan itu sendiri. Secara fungsi bangunan yang sekarang ini dipergunakan untuk kegiatan-kegiatan yang sifatnya adalah mengumpulkan masa atau pertemuan sesuai dengan yang dikemukanan oleh E. Widayati dkk., (2019).

Dalam sistem struktur bangunan Jawa, Pendopo Manggala Praja Nugraha struktur atap ditopang dan diikat olah saka (kolom atau tiang) yang kemudian diteruskan ke pondasi bangunan yang berbentuk umpak (pondasi setempat yang terbuat dari beton berbentuk trapesium). Kolom penyangga utama berjumlah 4 buah. Josef Prijotomo dalam Sulistijowati, (2016) menyampaikan perbedaan arsitektur Nusantara dengan arsitektur Eropa, khususnya dalam hal struktur yaitu Arsitektur Nusantara berkonstruksi tanggap gempa sedang arsitektur Eropa berkonstruksi tanpa gempa. Bentuk Joglo mempunyai sistem struktur penahan beban lateral melalui pembebanan pusat bangunan yang berupa saka guru dan tumpang sari (Frick, 1997), dengan tujuan agar bangunan menjadi berat dan stabil bila terkena gaya lateral. Berdasarkan pada kajian-kajian literatur di atas maka secara struktur bangunan ini sudah bergeser dari konsep bangunan rumah tradisional karena tidak lagi menerapkan struktur yang didesain untuk menahan gaya lateral akan tetapi sudah terikat secara permanen dengan kolom beton yang sifatnya rigit. 
Konsep warna Jawa berbeda dengan warna barat modern. Contoh konsep warna Jawa seperti gula kelapa (merah-putih) warna keraton Surakarta, kemudian pare anom (kuning-hijau) warna Mangkunegaran (Sumardjo, 2013). Dalam konteks interior unsur warna di dalam Pendopo Manggala Praja Nugraha di dominasi oleh warna alam yaitu kayu. Tidak menunjukkan ciri khas warna Jawa seperti halnya Kraton Surakarta maupun Mangkunegaran. Sehingga jika di telaah dari unsur warna sudah bergeser dari unsur budaya Jawa.

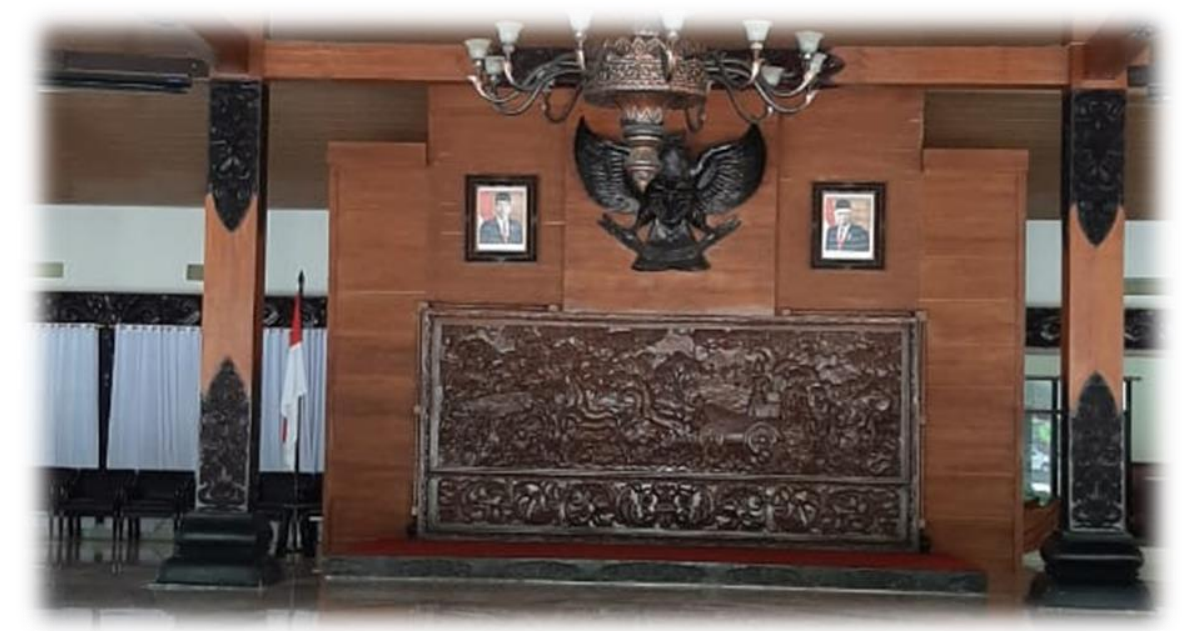

Gambar 6. Backdrop Pendapa Manggala Praja Nugraha Trenggalek (sumber:Survey, 2020)

\section{SIMPULAN}

Dari pembahasan di atas dapat disimpulkan bahwa dari sisi Bentuk Pendopo Manggala Praja Nugraha masih mengadop budaya Jawa, karena unsur Kepala, Badan dan Kaki masih terlihat jelas. Bentuk atap joglo menjadi ciri yang kuat yang melambangkan sebuah gunung. Begitu pula dengan denah yeng secara konseptual mempunyai arti filosofis yang menggambarkan bentuk geometri dari makro kosmos yakni Mancapat. Dari sisi ornamen-ornamen Pendopo Manggala Praja Nugraha hanya membawa 3 unsur budaya Jawa yakni ukiran dengan motif Praba, kemudian ornamen batik flora di lantai serta ornamen makhuto yang ada di bubungan atap joglo. Jika dilihat dari sisi ornamen sedikit sekali pendopo Manggala Praja Nugraha mengadopsi budaya Jawa. Dari konsep tata ruang, Pendopo Manggala Praja Nugraha terletak di depan namun maknanya sudah bergeser menjadi ruang semi publik karena sudah ada bangunan kuncung di depan dan juga ada dinding pembatas di bagian belakang. Dari aspek interior dalam hal ini aspek pewarnaan sudah bukan lagi mengadopsi bangunan budaya Jawa karena sudah berbeda dengan bangunan keraton yang asli. Sedangkan struktur bangunan yang ada juga sudah tidak menggunakan ikatan-ikatan lateral sebagaimana model rumah joglo yang asli. Jadi Sedikit sekali dari aspek ini membawa konsep budaya Jawa. 


\section{REFERENSI}

Budiharso, T. (2015). Meluruskan Sejarah Trenggalek Kota Gaplek: Studi Heuristik Foklor Panembahan Batoro Katong, Joko Lengkoro Dan Menak Sopal. LINGUA, 12(1), $137-$ 154.

Djono, T. P. Utomo, and S. S. (2012). Nilai Kearifan Lokal Rumah Tradisional Jawa. Humaniora, 24(3), 269-278.

Frick, H. (1997). Pola Struktur dan Teknik Bangunan di Indonesia. Kanisius, Yogyakarta and Soegijapranoto University Press.

Gerarda Orbita Ida Cahyandari. (2012). Jawa Di Yogyakarta Sebagai Wujud Kategori Pola. Jurnal Arsitektur Komposisi, 10(2).

Handinoto dan Paulus H. Soehargo. (1996). Perkembangan Kota dan Arsitektur Kolonial Belanda di Malang. Andi Offset.

Hermawan, B., \& Prihatmaji, Y. P. (2019). Perkembangan Bentukan Atap Rumah Tradisional Jawa. Prosiding Seminar Nasional Desain Dan Arsitektur (SENAD A), 2, 387-393.

Lukito Kartono, J. (2005). Konsep Ruang Tradisional Jawa dalam Konteks Budaya. Dimensi Interior, 3(2), 124-136.

Maria I Hidayatun. (1999). Pendopo dalam Era Modernisasi : Bentuk Fungsi dan Makna Pendopo pada Arsitektur Tradisional Jawa dalam Perubahan Kebudayaan. DIMENSI Jurnal Teknik Arsitektur), 27(1), 37-43. http://puslit2.petra.ac.id/ejournal/index.php/ars/article/view/15706

Pitana, T. S. (2007). Reproduksi Simbolik Arsitektur Tradisional Jawa : Memahami Ruang Hidup Material Manusia Jawa. GEMA TEKNIK Majalah Ilmiah Teknik, 10(2), 126-133.

Purwadi. (2011). Sejarah Kebudayaan Jawa (Issue November).

Rachman, M., \& Semarang, U. N. (2012). Konservasi Nilai Dan Warisan Budaya. Indonesian Journal of Conservation, 1(1), 30-39.

Ramdlani, S. (2012). Kedudukan Dan Fungsi Masjid Agung Terhadap Alun-Alun Kota Malang. Journal of Islamic Architecture, 1(1). https://doi.org/10.18860/jia.v1i1.1711

Sulistijowati, M. (2016). Struktur di Arsitektur Nusantara. TEMU ILMLAH IPLBI 2016 Struktur, 19-24.

Sumardjo, J. (2013). Estetika Nusantara. In Isi Press (Vol. 53, Issue 9). https://doi.org/10.1017/CBO9781107415324.004

Widayati, E., Rakhmawati, N., \& Pratama, D. (2019). The Architectural Structure of Joglo House as the Manifestation of Javanese Local Wisdom. WESTECH 2018. https://doi.org/10.4108/eai.8-12-2018.2283855

Widayati, N. (1999). Tinjauan Konsep Bangunan Jawa (Sebuah Kajian Literatur). Jurnal Kajian Teknologi, 1(1), 1-20. https://doi.org/10.1017/CBO9781107415324.004

Widiyatsari, S. (2002). Tata Ruang Rumah Bangsawan Yogyakarta. Dimensi Teknik Arsitektur, 30(2), 122-132. 